\title{
Impacts of rewetting on peat, hydrology and water chemical composition over 15 years in two finished peat extraction areas in Sweden
}

\author{
Lars Lundin (D) Torbjörn Nilsson • Sabine Jordan • Elve Lode • \\ Monika Strömgren
}

Received: 18 July 2016/ Accepted: 8 December 2016/Published online: 23 December 2016

(C) The Author(s) 2016. This article is published with open access at Springerlink.com

\begin{abstract}
Restoration of wetlands is a high priority world-wide. Peat extraction areas can be restored by rewetting, however affecting the environment. It could be expected to turn the drained peat-cutover area from a source to a sink of most elements. This study examined effects of such rewetting on peat, hydrology and water chemistry over 15 years at two sites in Sweden; the nutrient-poor Porla peatland and the nutrient-rich Västkärr peatland. Rewetting caused minor changes to peat chemistry, but at the Västkärr site ammonium concentrations increased in superficial peat layers while nitrate decreased. In terms of hydrology, rewetting of the Porla site decreased annual runoff and both high and low discharges. Water $\mathrm{pH}$ at the Porla site stayed fairly stable, but at the Västkärr site $\mathrm{pH}$, after an initial 4 years dip, gradually increased to higher values than before rewetting. Water colour and organic matter content were fairly stable, but slightly lower values were found after 15 years than in initial $4-5$ years. The concentrations of base cations and of inorganic $\mathrm{N}$ were lower after rewetting, while total $\mathrm{P}$ was higher. However, these impacts could change from an initial phase as the
\end{abstract}

L. Lundin $(\bowtie) \cdot$ T. Nilsson $\cdot$ S. Jordan .

E. Lode · M. Strömgren

Department of Soil and Environment, Swedish University of Agricultural Sciences, P.O. Box 7014, 75007 Uppsala,

Sweden

e-mail: Lars.Lundin@slu.se wetlands in the long-term perspective develop into mires.

Keywords After-use $\cdot$ Hydrochemistry $\cdot$ Peatland · Restoration · Wetland

\section{Introduction}

In total, four million $\mathrm{km}^{2}$ of the Earth's surface (circa $3 \%$ of the land area) are covered with peatlands, and peatlands are found in almost every country of the world (Schumann and Joosten 2008). It is especially abundant in vast areas of North Europe and Canada. The peatlands and peat resource is considered a societal asset and is used in agriculture, forestry, horticulture and as an energy source. These uses have resulted in numerous remnants of damaged mires, for which restoration is a high concern. Peatland restoration aims to improve environmental service values for biodiversity objectives, ecosystem functions, carbon storage, flood mitigation, deposition purification, etc. (Rochefort et al. 2003; Vasander et al. 2003; Ramchunder et al. 2012). Peat extraction has been carried out in many countries for at least 200 years. In Europe, peat losses have been considerable and in more than $50 \%$ of the original natural mire area peat organic material is no longer accumulating (Joosten and Clarke 2002). For a number of decades, it has been mandatory to find a suitable use for the remaining land 
after extraction ceases. In 1998, a new environmental law was established in Sweden, giving increased support for restoration.

There are multiple possibilities for wise after-use of former peat extraction areas (Joosten and Clarke 2002). On sites with low potential for forests or crop production, rehabilitation activities can seek to improve especially biodiversity values. Ecologically, wetland restoration has the main goal of bringing back disturbed terrestrial ecosystems and it aims to restore natural wetland hydrology (water level, flow paths and water chemistry) and to re-establish characteristic peatland plant cover (Vasander et al. 2003). For success in such operations, the starting conditions, i.e. the state of the peatland after peat extraction, should be considered, since it provides the main potential for successful end-results (Blankenburg and Tonnis 2004). Suitable indicators of wetland generation success include stable hydrology, appropriate water quality and vegetation development (Lode 2001).

Rewetting of cut-over peat would be the reverse of drainage; so many findings in forest drainage research could apply to conclusions for rewetting turning the effects of drainage back to the pre-drainage situation (Lundin 1988). Drainage also has effects on the water balance, providing space for precipitation in temporary surface water storage to be used in prolonged evapotranspiration and runoff. Such storage mitigates fast discharge responses. However, the storage capacity could be limited in situations when groundwater levels are high. In such circumstances, the ditches provide rapid channel flow capacity and possibly enhanced discharge peaks (Iritz et al. 1994). However, in general the effects of drainage on hydrology are lower peak flows, but somewhat higher annual runoff (Braekke 1970), accompanied by higher low discharge because the ditches promote release of water (Lundin 1988). In the case of rewetting, the reverse influence on discharge could be expected.

Not only hydrology is affected by peatland drainage, but also hydrochemistry. In the peatland formation process, when peat is accumulating and peat organic matter storage is increasing, there is sequestration of most chemical elements in the organic material. Drainage alters this process to decomposition when peat oxidation occurs and the stored elements are released (Sallantaus 1989). In drained conditions, higher outflow of most elements occurs, but the concentrations of dissolved organic matter (DOC) and protons in the leaching decrease, providing higher $\mathrm{pH}$. Nitrogen $(\mathrm{N})$ content changes from being dominated by the organic fraction $\left(\mathrm{N}_{\text {org }}, 80 \%\right)$ to inorganic nitrogen $\left(\mathrm{N}_{\text {inorg }}\right)$ release that can reach a level of $60 \%$ of total $\mathrm{N}\left(\mathrm{N}_{\mathrm{tot}}\right)$ (Lundin 1988). In the case of rewetting, a change from release to retention could be expected.

In modern industrial peat harvesting, the total peat resource is often extracted, with only thin remnants of peat left on top of mineral soil. This creates conditions strongly deviating from those in areas where a rather thick $(>1 \mathrm{~m})$ layer of peat still remains (Eggelsmann et al. 1993). There is probably some benefit in complete peat removal at one site, instead of affecting many sites by removing the top peat layer only. Such upper layer extraction keeps remnant peat conditions favourable and resembling the natural wetland properties, facilitating vegetation restoration. In the case of total peat extraction, the new, or actually very old, bottom peat layers and mineral soil, which have long been largely preserved from surface water and atmosphere interface processes, fall under the influence of new environmental processes. This situation gives rise to new hydro-chemical and biological conditions (Wheeler 1995).

This study primarily examined the impacts of peatland rewetting on properties of the peat, hydrology and water chemical conditions. The hypotheses tested were that rewetting former peat extraction areas:

- Elevates water levels but decreases discharge.

- Increases storage of most elements, however decreases $\mathrm{pH}$ and inorganic nitrogen (Ninorg) but increase DOC and phosphorus (P) concentrations in surface water.

\section{Methods}

Site description

The long-term rewetting investigations were carried out at two peat extraction sites c. one year before rewetting and in the initial 14 years after wetland establishment. The two sites were the Porla and Västkärr peatlands, both located in the south-west of central Sweden $\left(59^{\circ} 01^{\prime} \mathrm{N} ; 14^{\circ} 38^{\prime} \mathrm{E}\right.$ for the Porla site and $59^{\circ} 06^{\prime} \mathrm{N} ; 14^{\circ} 45^{\prime} \mathrm{E}$ for the Västkärr site) (Fig. 1). 

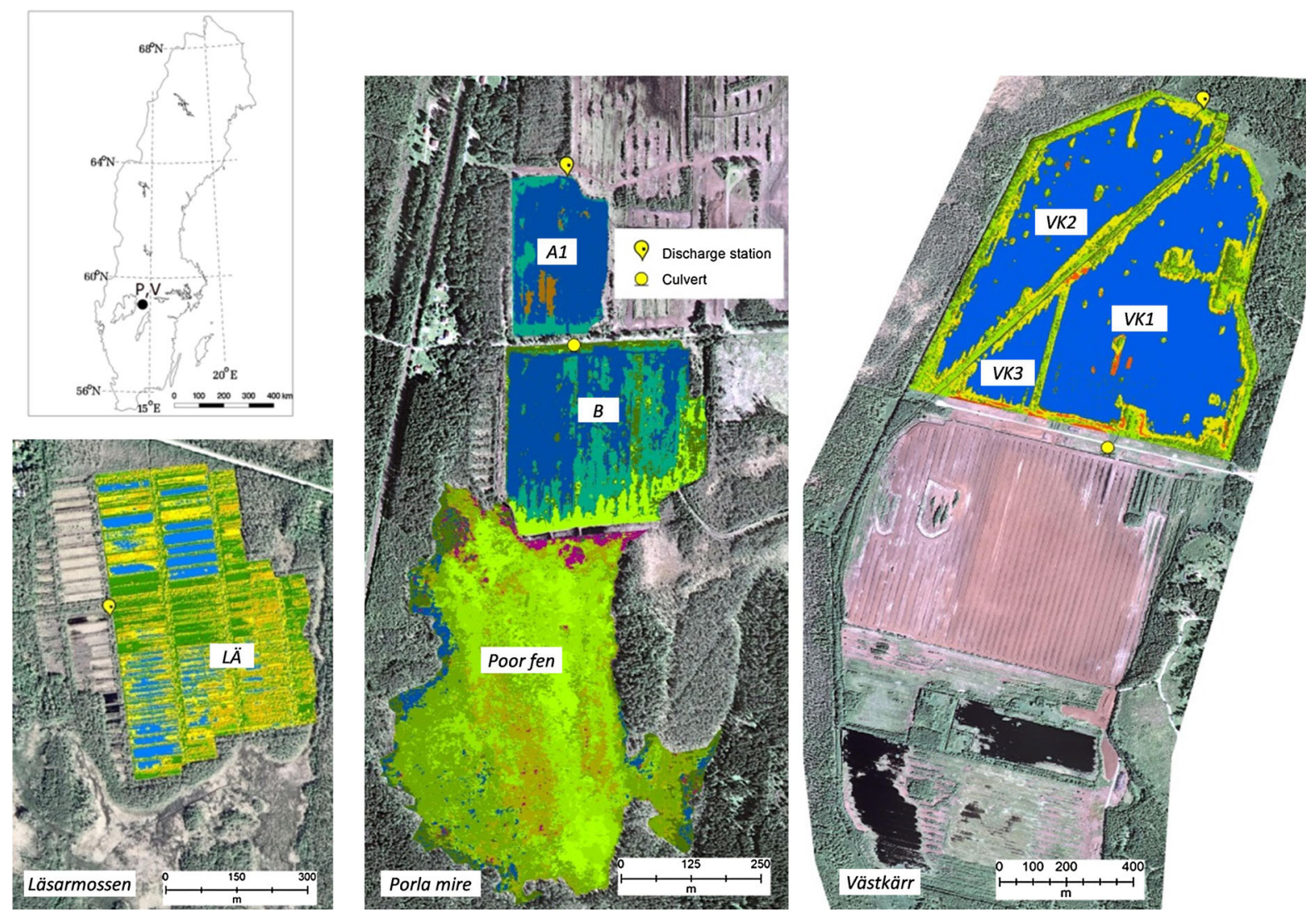

Fig. 1 Map of Sweden showing the location of the two rewetted areas Porla ( $A 1$ and $B$, middle picture) with the poor fen south of the wetlands and Västkärr (VK1-VK3, right picture) wetland in the north with a central ongoing peat cutover area and south of this another restored area and the reference $(L \ddot{A}$, left picture) to Porla. Colours represent: blue-open water, dark green-forest, light green and yellow-wetland plants, blueishgreen-wet peat mixed with plants and brown-bare peat
The Porla peatland was originally a raised bog where peat extraction started in 1889, with the level of activity varying over time. In the two last decades of the 20th century, peat was extracted down to the till soil of the morainic landscape. Residual peat thickness in the area prior to rewetting varied considerably, from 0 to $2 \mathrm{~m}$ depth, because of the stony till mineral soil underlying the peat. Only very small areas had mineral soil and thick 1-2 $\mathrm{m}$ peat cover was found on an estimated area of $20 \%$. In the remaining area the thickness was mainly $0.2-1 \mathrm{~m}$. Boulders and stones could be observed in many places and ordinary till hillocks and pits formed an uneven surface. South of the peat cut-over area there is a natural poor sedge fen (27 ha) that was excluded from the harvesting operations, from where discharging nutrient-poor water enters the Porla rewetting area. In 1999, rewetting was initiated by closing the drainage outlet with a water level-regulating device in the outlet ditch passing out in a culvert. A road divides the total restoration area into two parts, Porla A1 (5 ha) to the north and Porla B (12 ha) to the south. During rewetting operations, Porla A1 was surrounded by bunds built to store water and a discharge weir was installed at the outlet. The total catchment area at the outlet is 133 ha (Fig. 1). The total extraction area was about 55 ha, representing $48 \%$ of the Porla peatland. The catchment area at the site can be easily distinguished based on the drainage ditch network. Tree coverage, mainly spruce and pine, covered 34 ha, i.e. $29 \%$ of the previous mire extension. Due to varying peatland surface water conditions, the surface land cover was fragmented and varying in detail (Lode et al. 2012). Currently about $35 \%$ (19 ha) of the cut-over peatland has been rewetted, including areas rewetted by beaver inundation. Due to swelled and floating residual peat, the bare 
peat surface in the total wetland area constituted $25 \%$ for Lake A1 and 49\% for Lake B, with half of these surface areas covered by plants (Fig. 1).

The Västkärr wetland is located between the Skagerhultamossen raised bog in the west and mineral soil grassland in the east. Prior to peat extraction, a 80 ha lagg area of the large bog was cultivated for potatoes and cereal crops. At the end of peat extraction, there was rather even $0.1-0.2 \mathrm{~m}$ remaining peat thickness with comparatively high ash content overlying a level surface formed by postglacial clay soils. Inflowing groundwater, partly of minerogenic origin, furnished most of the rewetting water. In the extraction phase water was pumped out to keep the groundwater level low. In 1999, rewetting was initiated by stopping pumping water out of the area and a consecutive natural rise in the water level in the area gradually occurred, resulting in three shallow lakes formed as subbasins (VK 1, VK 2 and VK 3; Fig. 1). The catchment area for the Västkärr site is not easily determined because of undefined groundwater inflow from the surroundings and inflow from the large Skagerhultamossen bog and the nearby river Örebro Svartå.

In 1999, before the start of rewetting, both sites were prepared by soil and ground work and the surfaces mainly constituted bare, black, well-decomposed fen peat alternating with patches of mineral soil (Fig. 1). In Västkärr, the drains were filled in and the surface flattened. In Porla, bounds were built along the road in Porla B area and downslope, around half of the Porla A1 area.

In Västkärr, vegetation colonisation took place during the first growing season after rewetting started, but in Porla the first plant colonisation took longer time, partly owing to problems with keeping the water on-site. A few spots of Eriophorum vaginatum and Politrichum commune could be seen close to old ditches already after one season, but not until 2004-2005 did wider colonisation occur.

At both sites, the soil hydrology and water chemistry were studied, as well as vegetation development and greenhouse gas emissions from different ecotopes (Kozlov et al. 2016; Jordan et al. 2016).

As an unchanged reference area for the hydrology and hydrochemistry measurements at Porla, a nearby earlier self-restored cut-over area, Läsarmossen (LÄ) peatland was used. The LÄ peatland is located $2 \mathrm{~km}$ east of Porla wetland and was originally a 50 ha bog with on average a $3.7 \mathrm{~m}$ thick peat layer remaining. From 1940 to 1985 peat was hand-block-cut on 30 ha. The abandoned drainage system was partly blocked in 1989 and varying intensity of spontaneous re-colonisation occurred in inundated open pits (Lode 2001). In Porla the original peat thickness, estimated from the southern untouched low sedge fen, was 3.5-4.5 m. In the Västkärr lagg area, the original peat thickness is uncertain but values at start of peat cutting on $2 \mathrm{~m}$ was mentioned.

Climate conditions for the Porla and Västkärr sites were quite similar, as being rather close by located with long-term (1960-1990) mean annual precipitation of $800 \mathrm{~mm}$, evapotranspiration of $470 \mathrm{~mm}$ and temperature of $+5.7^{\circ} \mathrm{C}$ (Table 1) (Raab and Vedin 1995).

Precipitation in the period before rewetting (1997-1999) was slightly higher $(797 \mathrm{~mm})$ than in the period after rewetting (2000-2013; mean $752 \mathrm{~mm}$ ). In the period after rewetting precipitation was $9 \%$ higher than the long-term average and temperature was $0.7^{\circ} \mathrm{C}$ higher.

\section{Field measurements and sampling}

Field measurements of water depth and discharge and soil and water sampling were carried out in the period 1997-2013. Soil sampling was performed using corers, discharge determinations were made in $90^{\circ}$ $\mathrm{V}$-notch weirs with water level recorders at the notch and surface water sampling was carried out in wetlands and streams. Routine fortnightly field observations of water depth and monthly water sampling at the Porla and L $\ddot{\mathrm{A}}$ sites were carried out by a local

Table 1 Geographical, climate and hydrological (1961-1990) characteristics of the Porla and Västkärr peatland restoration areas (Raab and Vedin 1995)

\begin{tabular}{lll}
\hline Variable & Porla & Västkärr \\
\hline Altitude, m.a.s.l. & 85 & 65 \\
Rewetted peatland area, ha & 17 & 80 \\
Annual mean temperature, ${ }^{\circ} \mathrm{C}$ & 5.7 & 5.7 \\
Vegetation period $\left(\mathrm{T}>5{ }^{\circ} \mathrm{C}\right)$, days & 200 & 200 \\
Annual precipitation, $\mathrm{mm}$ & 800 & 800 \\
Annual evapotranspiration, mm & 470 & 470 \\
Annual runoff, mm & 330 & 330
\end{tabular}

Vegetation period is defined by daily average temperature exceeding $5{ }^{\circ} \mathrm{C}$ for four consecutive days (Odin et al. 1983) 
observer. Control visits for following instrument performance were made by the research team 2-6 times per year. Daily precipitation and temperature values were obtained from the Swedish Meteorological and Hydrological Institute.

Continuous discharge measurements at Porla outlet started in summer 1998 and at LÄ in 1996. For climate and technical reasons, discharge recording was interrupted for shorter or longer periods during 1997-2013. There are no full records for the period 2003-2006 for the Porla and LÄ sites.

Comparisons between the rewetted Porla and the reference LÄ site were carried out using the control area and calibration period technique (Grip 1982) and was applicable for both hydrology and water chemistry. The Porla rewet area was calibrated against the reference site for the period before rewetting and discharge for the following years could be calculated as non-rewetted. Measured discharge after rewetting was then compared against the calculated values without rewetting and the difference showed the change because of rewetting. The calibration period for discharge and water chemistry prior to rewetting was August 1998-August 1999.

At the Västkärr site, 10 soil samples $(0-10 \mathrm{~cm}$ depth) were taken before rewetting (1997) and after rewetting (in 2003 and 2007; 3-9 samples). The soil samples were taken using a steel auger $(4 \mathrm{~cm}$ diameter) from the superficial peat layer $(0-10 \mathrm{~cm})$. In rewetted conditions, the lake peat bottom and a little new formed sediment were sampled from the bottom layers $(0-10 \mathrm{~cm})$. At site Porla similar sampling of lake bottoms sediment and peat was conducted, but at 0-20 depth. Prior to rewetting 5 samples were included and in 2003 there were 3 samples and in 2007, 8 samples. Sampling locations were distributed over the areas and resampling made in approximately the same locations. All these soil samples were placed in plastic bags, transported to the laboratory in Uppsala and kept refrigerated at $4{ }^{\circ} \mathrm{C}$ until analyses. Before analysis, the samples were thawed, air-dried at $35^{\circ} \mathrm{C}$ and harmonised, grind through a $2 \mathrm{~mm}$ sieve. Nitrate $\left(\mathrm{NO}_{3}\right)$ and ammonium $\left(\mathrm{NH}_{4}\right)$ were analysed in fresh samples extracted with $2 \mathrm{M} \mathrm{KCl}$.

Water was sampled monthly at the Porla and LÄ sites and 4-6 times per year at Västkärr site. All samples were transported to SLU's accredited water laboratory in Uppsala within 1-2 days.
Chemical analysis

The $\mathrm{pH}$ in soil samples was determined in deionized water suspension ( $2 \mathrm{~g}$ dry peat in $25 \mathrm{~mL}$ water). Peat total carbon (C), $\mathrm{N}_{\text {tot }}$ and total sulphur (S) were analysed by dry combustion according to ISO 13,878 (CN2000, Leco). Calcium (Ca) and magnesium (Mg) were extracted by $\mathrm{NH}_{4} \mathrm{Ac}$ at $\mathrm{pH} 7$, while $2 \mathrm{M} \mathrm{HCl}$ was used to extract potassium $(\mathrm{K})$ and $\mathrm{P}\left(\mathrm{K}_{\mathrm{HCl}}\right.$ and $\left.\mathrm{P}_{\mathrm{HCl}}\right)$. After extraction, these elements were analysed by ICP-OES. Nitrate $\left(\mathrm{NO}_{3}\right)$ and ammonium $\left(\mathrm{NH}_{4}\right)$ were analysed in $100 \mathrm{~g}$ fresh samples extracted with $250 \mathrm{~mL} 2 \mathrm{M} \mathrm{KCl}$ and analysed with autoanalyzer.

Water samples were analysed for $\mathrm{pH}$, colour, electrical conductivity (EC), alkalinity, DOC, Na, K, $\mathrm{Ca}, \mathrm{Mg}$, manganese $(\mathrm{Mn})$, iron $(\mathrm{Fe})$, aluminium ( $\mathrm{Al})$, silicon $(\mathrm{Si})$, chloride $(\mathrm{Cl})$, sulphate $\left(\mathrm{SO}_{4}\right), \mathrm{NO}_{3}-\mathrm{N}$, $\mathrm{NH}_{4}-\mathrm{N}, \quad \mathrm{N}_{\text {org }}, \mathrm{N}_{\text {tot }}, \mathrm{PO}_{4}-\mathrm{P}$ and $\mathrm{P}_{\text {tot }}$ according to methods at the SLU accredited laboratory (SLU 2016). For $P$ the effect of water colour was eliminated by reduction for values in a blanc sample. For calculation of element runoff, daily discharge values and linear interpolated daily water chemical concentrations were used. Effects of rewetting on transport of chemical compounds were calculated using the calibration period and control area technique. The reference LÄ catchment values were correlated to the Porla catchment values for the period before rewetting. The relationship was then used together with the measured values at the reference for the rewetting period. These values were compared with values for the Porla catchment and the difference showed the effect of rewetting.

\section{Statistical calculations}

All variables studied were not normally distributed, at least during some of the study period. Therefore, before studying the effects of rewetting, all data were log-transformed to meet normality and homoscedasticity assumptions. ANOVA tests were performed to evaluate differences in water chemistry between different periods. ANOVA tests were performed to evaluate differences in water chemistry between different periods. A threshold of 0.05 was always used for significance. SAS $9.4^{\circledR}$ was used for all statistical analyses. 


\section{Results}

Peat soil properties

In the Västkärr area, the remaining peat layer after extraction was a fen sedge peat with thickness between 0 and $70 \mathrm{~cm}$, but over large areas mainly $10-20 \mathrm{~cm}$. Ash content was $10 \%$ higher than in former extracted layers. The remaining peat layer bulk density varied mainly between $0.2 \mathrm{~g} \mathrm{~cm}^{-3}$ and $0.3 \mathrm{~g} \mathrm{~cm}^{-3}$, overlying $5 \mathrm{~cm}$ gyttja with bulk density $0.4-1.0 \mathrm{~g} \mathrm{~cm}^{-3}$. Under this, postglacial clay occurred. At the Porla site after extraction, there was larger variation in peat thickness (0-2 m). In many places Carex/Equisetum and Equisetum/Carex peat $0.7-1 \mathrm{~m}$ thick was present. These layers were in some places overlain by Sphagnum peat with thickness of mainly $0.4-0.6 \mathrm{~m}$. Bulk density decreased from $0.1 \mathrm{~g} \mathrm{~cm}^{-3}$ to $0.04 \mathrm{~g} \mathrm{~cm}^{-3}$ in the first years after rewetting, but returned to almost $0.1 \mathrm{~g} \mathrm{~cm}^{-3}$ after eight years.

Prior to rewetting, the chemical composition of peat at the two sites differed, as it was more nutrient rich at site Västkärr than at site Porla. Peat values in Västkärr from 0 to $10 \mathrm{~cm}$ depth and Porla $0-20 \mathrm{~cm}$ gave the $\mathrm{CN}$ ratio, based on $\mathrm{g} \mathrm{g}^{-1}$, on 21 and 47, respectively, with peat $\mathrm{pH} 5.0$ and 4.4, respectively. However, the water chemistry showed larger differences, with $\mathrm{pH}$ 6-7 in water at the Västkärr site and 5-5.5 at Porla site. Considerable differences in peat chemistry between the two sites were observed for inorganic N, P and K (Table 2).

At the nutrient-rich Västkärr site, rewetting changed the chemical characteristics in peat and lake sediment somewhat, but mainly only minor changes occurred. The $\mathrm{pH}$ and $\mathrm{C}$ and $\mathrm{N}$ concentrations increased slightly, but this did not change the $\mathrm{CN}$ ratio. Exchangeable $\mathrm{Ca}$ and $\mathrm{Mg}$ concentrations increased after rewetting, while the concentrations of $\mathrm{K}_{\mathrm{HCl}}$ and $\mathrm{P}_{\mathrm{HCl}}$ decreased to $365 \mathrm{mg} \mathrm{kg}^{-1}$ and $565 \mathrm{mg} \mathrm{kg}^{-1}$, respectively. Before rewetting, the concentrations of $\mathrm{NH}_{4}-\mathrm{N}$ were negligible while $\mathrm{NO}_{3}$ $\mathrm{N}$ was present in higher concentrations ( $50 \mathrm{mg} \mathrm{kg}^{-1}$ ). After rewetting the picture was reversed and $\mathrm{NH}_{4}-\mathrm{N}$ became dominant on $115 \mathrm{mg} \mathrm{kg}^{-1}$ while $\mathrm{NO}_{3}-\mathrm{N}$ was almost depleted $\left(0.7 \mathrm{mg} \mathrm{kg}^{-1}\right)$.

Peat physical and chemical conditions in Porla wetland changed after rewetting. The $\mathrm{pH}$ increased up to four years to 4.8 but decreased thereafter to 4.2 after 8 years. The concentrations of $\mathrm{C}$ and especially $\mathrm{N}$ increased to $1.6 \%$, resulting in lower $\mathrm{CN}$ ratio on c. 30 . Concentrations of extractable $\mathrm{P}_{\mathrm{HCl}}$ and $\mathrm{K}_{\mathrm{HCl}}$ in the upper part of the peat $(0-20 \mathrm{~cm})$ changed after rewetting, with $\mathrm{P}$ reaching higher values on $350 \mathrm{mg} \mathrm{kg}^{-1}$ while $\mathrm{K}$ decreased to $53 \mathrm{mg} \mathrm{kg}^{-1}$ after eight years. Amounts of both elements decreased over time and lower BD contributed to this.

\section{Hydrology}

In the humid climate of south-west Sweden with excess precipitation of $330 \mathrm{~mm}$ over evapotranspiration (Table 1), rewetting was a suitable option for restoration and the drained cut-over areas quickly received inflowing water, forming wetlands. The necessary water storage in the wetlands was estimated to make up $15 \%$ of the annual runoff. At both the Porla and Västkärr sites, the open water reservoirs formed only a few months after rewetting, 6 and 2 months, respectively. In the Porla wetland, some initial
Table 2 Chemical characteristics of the peat at the Västkärr (depth $0-10 \mathrm{~cm})$ and Porla (depth 0-20 cm) sites before rewetting

$C V$ coefficient of variation, $n$ number of samples, $d w$ dry weight

\begin{tabular}{lllll}
\hline Variable & $\begin{array}{l}\text { Porla } \\
\mathrm{n}=5\end{array}$ & $\mathrm{CV}(\%)$ & $\begin{array}{l}\text { Västkärr } \\
\mathrm{n}=10\end{array}$ & $\mathrm{CV}(\%)$ \\
\hline $\mathrm{pH}$ & 4.4 & 6 & 5.0 & 6 \\
$\mathrm{C}(\%)$ & 50 & 4 & 43 & 12 \\
$\mathrm{~N}(\%)$ & 1.1 & 33 & 2.0 & 9 \\
$\mathrm{C} / \mathrm{N}$ & 47 & 29 & 21 & 6 \\
$\mathrm{NO}_{3}-\mathrm{N}, \mathrm{mg} / \mathrm{kg} \mathrm{dw}$ & 2 & 160 & 57 & 54 \\
$\mathrm{NH}_{4}-\mathrm{N}, \mathrm{mg} / \mathrm{kg} \mathrm{dw}$ & 88 & 92 & 0 & - \\
$\mathrm{K}_{\mathrm{HCl}}, \mathrm{mg} / \mathrm{kg} \mathrm{dw}$ & 92 & 80 & 460 & 32 \\
$\mathrm{P}_{\mathrm{HCl}}, \mathrm{mg} / \mathrm{kg} \mathrm{dw}$ & 320 & 50 & 650 & 19 \\
\hline
\end{tabular}


mishaps lowered the lake water level twice, in 2001 and 2002, to $0.1-0.2 \mathrm{~m}$ depth, but after that it stabilised at around $1 \mathrm{~m}$ depth in central parts. In the Västkärr lakes, the water levels remained fairly stable from the beginning of rewetting, with depth between 0.5 and $1 \mathrm{~m}$ and occasional maximum depth up to $2 \mathrm{~m}$.

Filling up the water reservoirs three times at Porla resulted in short periods when the discharge was lower than in the reference LÄ conditions, but discharge and water storage later stabilised. Measured annual runoff from Porla wetland was lower than calculated annual runoff based on the reference LÄ conditions. Lower annual runoff was observed for 2007-2009 and 2013, while the period 2010-2012 had runoff similar to the calculated value for non-rewetted conditions. For the period before rewetting, average runoff from the Porla catchment was $60 \%$ of the reference $\mathrm{LA}$ value (403 mm) but after rewetting it only reached about $40 \%$ of the reference value $(500 \mathrm{~mm})$. This implies decreased average runoff after rewetting. Discharge (expressed in $\mathrm{L} \mathrm{s}^{-1}$ ) was fairly similar for the Porla catchment and the reference before rewetting (1998/ 1999), but was lower at Porla after rewetting (Fig. 2).

Effects of rewetting on high and low discharge were investigated on a daily basis. Before rewetting there was only one period (14 March-31 August 1999) with reliable daily runoff measurements for both the Porla and LÄ catchments. During this period there were fewer days with high runoff at Porla than at the reference site. For the period after rewetting, with

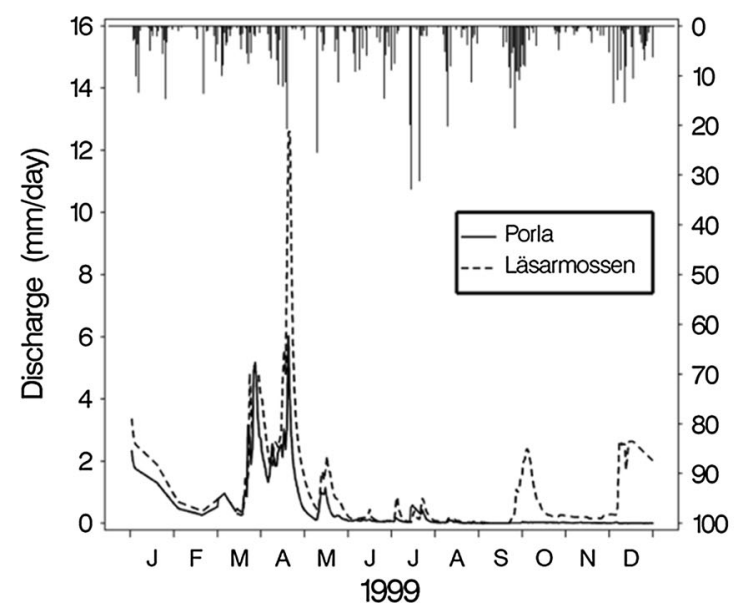

Fig. 2 Daily precipitation (upper bars) and discharge from the reference Läsarmossen (LÄ) catchment (broken line) and the cut-over later rewetted Porla catchment (solid line) in 1999 (left) years 2001 and 2002 omitted because of the hydrotechnical problems at Porla site. For the period 2007-2013 the frequency of high and very high runoff values was lower than before rewetting in both catchments. However, the frequency of high flows (1-3 mm day ${ }^{-1}$ ) decreased more at Porla (180 days) than at the reference site (620 days), and the frequency of days $(0.6 \%$ compared to $3.8 \%)$ with very high runoff ( $>3 \mathrm{~mm} \mathrm{day}^{-1} ; 35 \mathrm{~L} \mathrm{~s}^{-1} \mathrm{~km}^{-2}$ ) decreased considerably more in the rewetted catchment.

Before rewetting, the Porla catchment had a higher frequency (22\%) of days with low daily runoff $\left(<0.05 \mathrm{~mm} \mathrm{day}^{-1}\right)$ compared with the reference site (11\%). In rewetting conditions (2007-2013) the frequency of days with low runoff increased to $42 \%$ at the rewetted site, while the reference catchment only had a frequency of $15 \%$. The frequency of very low water flows $\left(<0.01 \mathrm{~mm} \mathrm{day}^{-1}\right)$ or no flow at all after rewetting was also significantly higher for the rewetted area compared with the reference with 18 and $6 \%$, respectively out of 3342 days after rewetting. Low discharge occurred in several years during summer.

\section{Wetland water chemistry}

Västkärr wetland

Water chemistry in the nutrient-rich Västkärr wetland showed mainly lower ion contents after rewetting. The

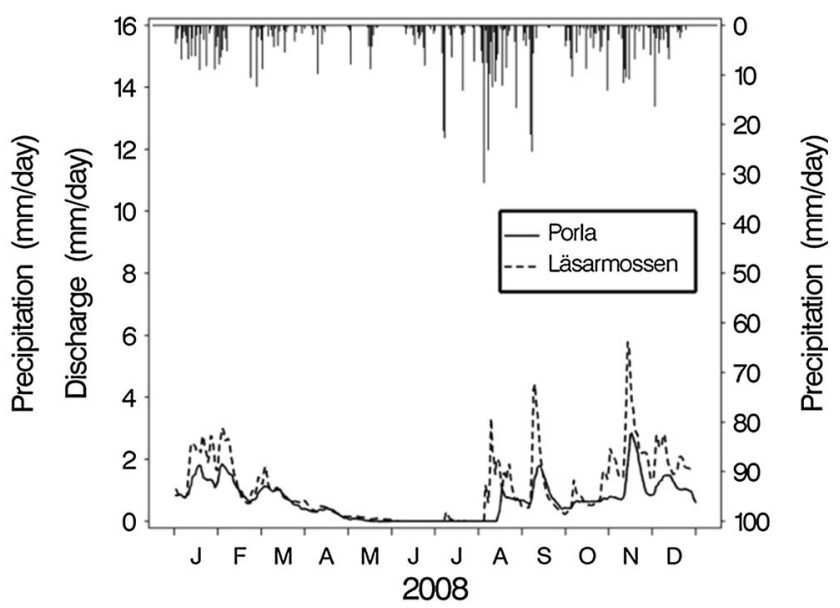

mainly before rewetting (water storage started in September) and 9 years after Porla rewetting 2008 (right) 
$\mathrm{pH}$ increased but EC, base cations, $\mathrm{Si}$ and inorganic $\mathrm{N}$ decreased. The concentrations of $\mathrm{Fe}, \mathrm{Al}$, organic $\mathrm{N}$ and $\mathrm{P}_{\text {tot }}$ increased, while $\mathrm{PO}_{4}-\mathrm{P}$ decreased (Table 3).

In the Västkärr cut-over peat area, mean $\mathrm{pH}$ before rewetting was slightly over 6 . During the initial years after rewetting $\mathrm{pH}$ was on average 6.2 , but then increased to significantly higher values than before rewetting and was on average 6.7 at 12-14 years after rewetting (Table 3). Before rewetting, mean annual DOC concentration varied between 37 and $48 \mathrm{mg} \mathrm{L}^{-1}$ and during the year that rewetting started (1999) it increased to $58 \mathrm{mg} \mathrm{L}^{-1}$. In the following years it then decreased to values that were usually significantly lower (34-38 $\left.\mathrm{mg} \mathrm{L}^{-1}\right)$ than before rewetting (Table 3).

Before rewetting of the Västkärr wetland, the concentrations of inorganic and organic $\mathrm{N}$ were similar but decreased and increased, respectively, after rewetting, resulting in a $\mathrm{N}_{\text {inorg }}$ to $\mathrm{N}_{\text {org }}$ ratio of about $30 \%$ (Fig. 3). The $\mathrm{N}_{\text {inorg }}$ fraction of total $\mathrm{N}$ was c. $20 \%$. Total $\mathrm{N}$ decreased somewhat after rewetting, but values were similar to those before rewetting (Table 3).

Water phosphorus concentration before rewetting was $0.03 \mathrm{mg} \mathrm{L}^{-1}$ and almost all was present as $\mathrm{PO}_{4}-\mathrm{P}$. In the initial 3 years after rewetting, $\mathrm{PO}_{4}-\mathrm{P}$ concentration remained almost unchanged, while $\mathrm{P}_{\text {tot }}$ increased about threefold (Fig. 4). In the years after rewetting, $\mathrm{PO}_{4}-\mathrm{P}$ concentration decreased to half the value before rewetting (Table 3). Total $\mathrm{P}$ also decreased in later years, but remained about $100 \%$ higher than before rewetting. The share of $\mathrm{PO}_{4}-\mathrm{P}$ to $\mathrm{P}_{\text {tot }}$ changed from $90 \%$ before rewetting to about $20 \%$ thereafter (Fig. 4).

Table 3 Chemical composition (mean \pm standard error) of water in the Västkärr wetland before rewetting (1997-1998) and for four periods after rewetting

\begin{tabular}{|c|c|c|c|c|c|c|}
\hline Variable & Units & $\begin{array}{l}1997-1998 \\
n=29\end{array}$ & $\begin{array}{l}1999-2001 \\
n=35\end{array}$ & $\begin{array}{l}2002-2006 \\
n=40\end{array}$ & $\begin{array}{l}2007-2010 \\
\mathrm{n}=31\end{array}$ & $\begin{array}{l}2011-2013 \\
\mathrm{n}=34\end{array}$ \\
\hline $\mathrm{pH}$ & & $6.06 \pm 0.11 \mathrm{c}$ & $6.16 \pm 0.04 \mathrm{c}$ & $6.66 \pm 0.05 \mathrm{~b}$ & $6.95 \pm 0.06 \mathrm{a}$ & $6.68 \pm 0.05 b$ \\
\hline $\mathrm{EC}$ & $\mu \mathrm{S} \mathrm{cm}-1$ & $247 \pm 26 \mathrm{a}$ & $76.5 \pm 2.7 \mathrm{c}$ & $82.0 \pm 3.2 \mathrm{c}$ & $89.8 \pm 5.1 \mathrm{bc}$ & $99.2 \pm 5.2 b$ \\
\hline Alkalinity & $\mathrm{mg} \mathrm{L}^{-1}$ & $27.2 \pm 6.1 \mathrm{~b}$ & $17.6 \pm 1.7 \mathrm{a}$ & $19.6 \pm 1.4 \mathrm{a}$ & $25.8 \pm 3.5 \mathrm{a}$ & $25.6 \pm 2.5 \mathrm{a}$ \\
\hline SS & $\mathrm{mg} \mathrm{L}^{-1}$ & $17.4 \pm 2.8$ & $12.7 \pm 2.3$ & $9.51 \pm 0.92$ & $21.2 \pm 2.9$ & $21.5 \pm 3.7$ \\
\hline Colour & $\mathrm{mg} \mathrm{Pt} \mathrm{L}^{-1}$ & $160 \pm 16 \mathrm{c}$ & $258 \pm 16 \mathrm{ab}$ & $175 \pm 10 \mathrm{bc}$ & $200 \pm 11 \mathrm{ab}$ & $187 \pm 13 b$ \\
\hline DOC & $\mathrm{mg} \mathrm{L}^{-1}$ & $44.9 \pm 3.7 \mathrm{ab}$ & $47.6 \pm 2.2 \mathrm{a}$ & $33.7 \pm 1.5 \mathrm{c}$ & $37.6 \pm 1.4 \mathrm{bc}$ & $36.0 \pm 1.3 \mathrm{c}$ \\
\hline $\mathrm{Ca}$ & $\mathrm{mg} \mathrm{L}^{-1}$ & $41.1 \pm 4.5 \mathrm{a}$ & $12.6 \pm 0.5 \mathrm{~cd}$ & $12.2 \pm 0.6 \mathrm{~d}$ & $15.6 \pm 1.1 \mathrm{~b}$ & $15.5 \pm 1.3 \mathrm{bc}$ \\
\hline $\mathrm{Mg}$ & $\mathrm{mg} \mathrm{L}^{-1}$ & $5.84 \pm 0.65 \mathrm{a}$ & $1.81 \pm 0.09 \mathrm{~cd}$ & $1.70 \pm 0.08 \mathrm{~d}$ & $2.10 \pm 0.12 b c$ & $2.15 \pm 0.15 b$ \\
\hline $\mathrm{K}$ & $\mathrm{mg} \mathrm{L}^{-1}$ & $2.95 \pm 0.61 \mathrm{a}$ & $1.39 \pm 0.12 \mathrm{~b}$ & $1.41 \pm 0.09 \mathrm{~b}$ & $1.62 \pm 0.10 \mathrm{~b}$ & $1.60 \pm 0.14 \mathrm{~b}$ \\
\hline $\mathrm{Na}$ & $\mathrm{mg} \mathrm{L}^{-1}$ & $5.41 \pm 0.55 \mathrm{a}$ & $3.02 \pm 0.10 \mathrm{c}$ & $3.35 \pm 0.13 \mathrm{c}$ & $4.31 \pm 0.17 \mathrm{ab}$ & $4.08 \pm 0.22 b$ \\
\hline $\mathrm{Fe}$ & $\mathrm{mg} \mathrm{L}^{-1}$ & $1.67 \pm 0.28 \mathrm{~b}$ & $2.91 \pm 0.26 \mathrm{a}$ & $2.36 \pm 0.18 \mathrm{a}$ & $3.07 \pm 0.24 \mathrm{a}$ & $2.77 \pm 0.28 \mathrm{a}$ \\
\hline $\mathrm{Al}$ & $\mathrm{mg} \mathrm{L}^{-1}$ & $0.39 \pm 0.06 \mathrm{a}$ & $0.31 \pm 0.03 \mathrm{a}$ & $0.21 \pm 0.02 \mathrm{~b}$ & $0.38 \pm 0.03 \mathrm{a}$ & $0.32 \pm 0.03 \mathrm{a}$ \\
\hline $\mathrm{Si}$ & $\mathrm{mg} \mathrm{L}^{-1}$ & $3.48 \pm 0.61 \mathrm{a}$ & $1.41 \pm 0.17 \mathrm{~b}$ & $1.39 \pm 0.17 \mathrm{~b}$ & $2.55 \pm 0.51 \mathrm{~b}$ & $1.45 \pm 0.30 \mathrm{~b}$ \\
\hline $\mathrm{Mn}$ & $\mathrm{mg} \mathrm{L}^{-1}$ & $1.09 \pm 0.24 \mathrm{a}$ & $0.13 \pm 0.03 \mathrm{c}$ & $0.18 \pm 0.04 \mathrm{~b}$ & $0.28 \pm 0.09 \mathrm{~b}$ & $0.22 \pm 0.06 \mathrm{~b}$ \\
\hline $\mathrm{Cl}$ & $\mathrm{mg} \mathrm{L}^{-1}$ & $4.61 \pm 0.25 b c$ & $4.00 \pm 0.15 \mathrm{c}$ & $4.69 \pm 0.20 \mathrm{~b}$ & $5.78 \pm 0.25 \mathrm{a}$ & $5.00 \pm 0.21 b$ \\
\hline $\mathrm{SO}_{4}-\mathrm{S}$ & $\mathrm{mg} \mathrm{L}^{-1}$ & $3.08 \pm 0.81 \mathrm{a}$ & $1.93 \pm 0.19 b$ & $2.62 \pm 0.16 \mathrm{a}$ & $3.06 \pm 0.17 \mathrm{a}$ & $2.81 \pm 0.22 \mathrm{a}$ \\
\hline $\mathrm{NO}_{3}-\mathrm{N}$ & $\mathrm{mg} \mathrm{L}^{-1}$ & $0.63 \pm 0.19 \mathrm{a}$ & $0.23 \pm 0.05 \mathrm{a}$ & $0.15 \pm 0.03 b$ & $0.14 \pm 0.04 \mathrm{~b}$ & $0.18 \pm 0.04 \mathrm{a}$ \\
\hline $\mathrm{NH}_{4}-\mathrm{N}$ & $\mathrm{mg} \mathrm{L}^{-1}$ & $0.64 \pm 0.13 \mathrm{a}$ & $0.46 \pm 0.07 \mathrm{a}$ & $0.19 \pm 0.04 \mathrm{~b}$ & $0.33 \pm 0.13 \mathrm{ab}$ & $0.36 \pm 0.10 \mathrm{a}$ \\
\hline $\mathrm{N}_{\text {org }}$ & $\mathrm{mg} \mathrm{L}^{-1}$ & $1.31 \pm 0.16 \mathrm{c}$ & $1.69 \pm 0.11 \mathrm{ab}$ & $1.37 \pm 0.07 \mathrm{bc}$ & $1.49 \pm 0.20 \mathrm{c}$ & $1.70 \pm 0.06 \mathrm{a}$ \\
\hline $\mathrm{N}_{\text {tot }}$ & $\mathrm{mg} \mathrm{L}^{-1}$ & $2.58 \pm 0.21 \mathrm{a}$ & $2.38 \pm 0.12 \mathrm{a}$ & $1.70 \pm 0.07 \mathrm{~b}$ & $1.92 \pm 0.25 \mathrm{~b}$ & $2.24 \pm 0.13 \mathrm{a}$ \\
\hline $\mathrm{PO}_{4}-\mathrm{P}$ & $\mu \mathrm{g} \mathrm{L}^{-1}$ & $31 \pm 10 \mathrm{ab}$ & $33 \pm 6 a$ & $18 \pm 3 \mathrm{bc}$ & $10 \pm 2 \mathrm{~d}$ & $16 \pm 4 \mathrm{~cd}$ \\
\hline $\mathrm{P}_{\text {tot }}$ & $\mu \mathrm{g} \mathrm{L}^{-1}$ & $34 \pm 4 \mathrm{~d}$ & $104 \pm 10 \mathrm{a}$ & $72 \pm 7 \mathrm{bc}$ & $58 \pm 5 \mathrm{~cd}$ & $76 \pm 5 a b$ \\
\hline
\end{tabular}

Qcalc. is calculated runoff based on reference LÄ catchment data and reflects non-rewetted conditions. Qmeas. is measured runoff for the Porla catchment

The change, $\Delta \mathrm{Q}$, was calculated in $\mathrm{mm}$ and as a percentage of Qcalc 
Fig. 3 Inorganic $\left(\mathrm{N}_{\text {inorg }}\right)$ and organic $\left(\mathrm{N}_{\text {org }}\right)$ nitrogen concentrations in Västkärr wetland, 1997-2013. Left Mean values for sub-areas and periods. Right ratio of Ninorg to Norg

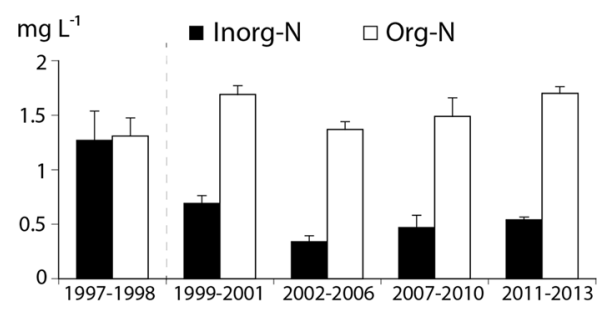

Inorg-N/Org-N

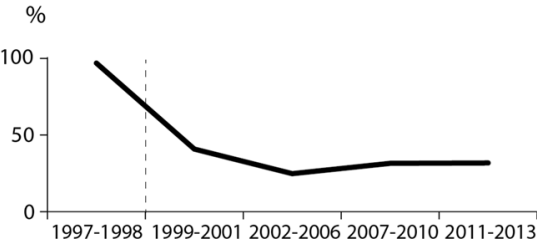

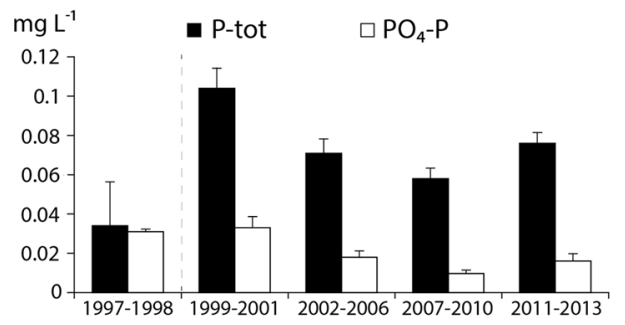

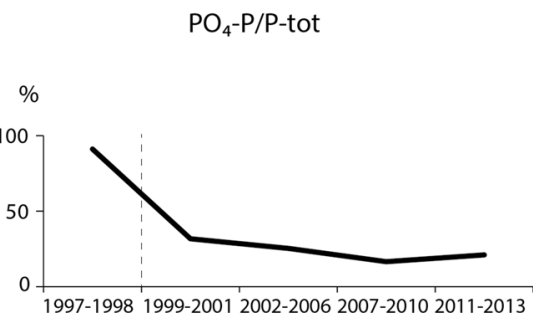

Fig. 4 Concentrations of total phosphorus $\left(\mathrm{P}_{\text {tot }}\right)$ and phosphate-P $\left(\mathrm{PO}_{4}-\mathrm{P}\right)$ in Västkärr wetland, 1997-2013. Left Mean values for the sub-areas and periods. Right ratio of $\mathrm{PO}_{4}-\mathrm{P}$ to $\mathrm{P}_{\text {tot }}$

\section{Porla wetland}

Prior to rewetting, the $\mathrm{pH}$ in the outlet water was higher and displayed considerable variation compared with after rewetting, when the value stabilised at a lower level than before rewetting. In the first four-year period after rewetting changes were minor, but in the next $5-14$ years the $\mathrm{pH}$ was on average 0.4 units lower (Table 4).

Changes in chemical composition after rewetting appeared as darker water for the first 11 years, but in years 12-14 water colour decreased to the same level as before rewetting. Water DOC concentration in the first 11 years changed to a minor extent, with both increases and decreases, but in the last three-year period there was a greater decrease, i.e. in agreement with water colour (Table 4). Base cations and metals together with Si mainly showed lower values compared with before rewetting, with some slight deviations for $\mathrm{Na}, \mathrm{K}$ and $\mathrm{Al}$ (Table 4). Bicarbonate alkalinity occurred a few times before rewetting and in the first years of rewetting, but after four years became zero in line with the low $\mathrm{pH}$. Anions such as $\mathrm{SO}_{4}, \mathrm{Cl}$ and $\mathrm{NO}_{3}$ mainly decreased under rewetted conditions, with $\mathrm{Cl}$ as the dominant anion. Total $\mathrm{N}$ decreased, especially in the last six-year period, when $\mathrm{N}_{\text {org }}$ also showed lower values, agreeing with lower DOC and water colour in that period (Table 4). Before rewetting, $\mathrm{N}_{\text {org }}$ comprised on average $52 \%$ of $\mathrm{N}_{\text {tot }}$, but decreased to $47 \%$ of $\mathrm{N}_{\text {tot }}$ in the first 4 years of rewetting and then rose steadily to reach $79 \%$ in 12-14 years after rewetting. The concentration of $\mathrm{NH}_{4}-\mathrm{N}$ prior to rewetting was an order of magnitude higher than the $\mathrm{NO}_{3}-\mathrm{N}$ concentration, but decreased significantly in years 5-14 after rewetting. $\mathrm{NO}_{3}-\mathrm{N}$ reached lower values after rewetting than before (Fig. 5).

Total $\mathrm{P}$ increased in the first year after rewetting to over $0.02 \mathrm{mg} \mathrm{L}^{-1}$, but reverted to slightly lower values after 4-5 years. Median $\mathrm{P}_{\text {tot }}$ concentration was $0.015 \mathrm{mg} \mathrm{L}^{-1}$ before rewetting and increased to $0.019 \mathrm{mg} \mathrm{L}^{-1}$ after rewetting implying that slightly higher values were observed in rewetted condition (Fig. 6) The $\mathrm{PO}_{4}-\mathrm{P}$ content was $0.003 \mathrm{mg} \mathrm{L}^{-1}$ before rewetting and increased slightly to $0.004 \mathrm{mg} \mathrm{L}^{-1}$ after rewetting, making up about $20 \%$ of $\mathrm{P}_{\text {tot }}$ (Table 4; Fig. 6).

Leaching of elements from the Porla wetland

For the Porla catchment, where discharge measurements were possible, chemical element flows were calculated. Measured discharge and water chemistry concentrations were used to compute flow values and these were compared with calculated non-rewetted values estimated from the reference catchment. Most 
Table 4 Chemical composition (mean \pm SE) of water in the Porla wetland before (1998-1999) and for four periods after rewetting

\begin{tabular}{|c|c|c|c|c|c|c|}
\hline Variable & Units & $\begin{array}{l}1998-1999 \\
\mathrm{n}=11-17\end{array}$ & $\begin{array}{l}2000-2003 \\
\mathrm{n}=40\end{array}$ & $\begin{array}{l}2004-2006 \\
\mathrm{n}=17-18\end{array}$ & $\begin{array}{l}2007-2010 \\
n=40-45\end{array}$ & $\begin{array}{l}2011-2013 \\
\mathrm{n}=34\end{array}$ \\
\hline $\mathrm{pH}$ & & $5.38 \pm 0.14 \mathrm{a}$ & $5.08 \pm 0.06 \mathrm{~b}$ & $4.88 \pm 0.03 \mathrm{c}$ & $4.98 \pm 0.01 \mathrm{bc}$ & $4.99 \pm 0.02 \mathrm{bc}$ \\
\hline $\mathrm{EC}$ & $\mu \mathrm{S} \mathrm{cm}-1$ & $43.0 \pm 2.3 \mathrm{a}$ & $35.4 \pm 1.3 b$ & $31.3 \pm 1.4 \mathrm{c}$ & $27.3 \pm 0.5 \mathrm{~d}$ & $29.0 \pm 1.0 \mathrm{~cd}$ \\
\hline Alkalinity & $\mathrm{mg} \mathrm{L}^{-1}$ & $3.66 \pm 1.64 \mathrm{a}$ & $1.36 \pm 0.53 \mathrm{~b}$ & $0.0 \pm 0.0 \mathrm{c}$ & $0.0 \pm 0.0 \mathrm{c}$ & $0.0 \pm 0.0 \mathrm{c}$ \\
\hline SS & $\mathrm{mg} \mathrm{L}^{-1}$ & $15.5 \pm 5.7 \mathrm{ab}$ & $11.2 \pm 2.3 \mathrm{a}$ & $4.82 \pm 0.42 \mathrm{ab}$ & $5.86 \pm 0.63 \mathrm{~b}$ & $4.71 \pm 0.92 \mathrm{c}$ \\
\hline Colour & $\mathrm{mg} \mathrm{Pt} \mathrm{L}{ }^{-1}$ & $223 \pm 16 b$ & $233 \pm 10 \mathrm{ab}$ & $242 \pm 10 \mathrm{ab}$ & $252 \pm 8 \mathrm{a}$ & $214 \pm 10 b$ \\
\hline DOC & $\mathrm{mg} \mathrm{L}^{-1}$ & $34.4 \pm 2.1 \mathrm{ab}$ & $33.7 \pm 1.0 \mathrm{a}$ & $33.8 \pm 1.5 \mathrm{ab}$ & $33.8 \pm 0.9 \mathrm{a}$ & $30.4 \pm 1.1 \mathrm{~b}$ \\
\hline $\mathrm{Ca}$ & $\mathrm{mg} \mathrm{L}^{-1}$ & $4.43 \pm 0.45 \mathrm{a}$ & $2.56 \pm 0.31 \mathrm{~b}$ & $1.68 \pm 0.09 \mathrm{c}$ & $1.90 \pm 0.07 \mathrm{bc}$ & $2.09 \pm 0.10 \mathrm{bc}$ \\
\hline $\mathrm{Mg}$ & $\mathrm{mg} \mathrm{L}^{-1}$ & $1.06 \pm 0.07 \mathrm{a}$ & $0.56 \pm 0.04 \mathrm{c}$ & $0.55 \pm 0.03 \mathrm{c}$ & $0.65 \pm 0.02 b$ & $0.71 \pm 0.03 \mathrm{~b}$ \\
\hline $\mathrm{K}$ & $\mathrm{mg} \mathrm{L}^{-1}$ & $0.46 \pm 0.06 \mathrm{a}$ & $0.47 \pm 0.03 \mathrm{a}$ & $0.50 \pm 0.03 \mathrm{a}$ & $0.45 \pm 0.02 \mathrm{a}$ & $0.42 \pm 0.03 \mathrm{a}$ \\
\hline $\mathrm{Na}$ & $\mathrm{mg} \mathrm{L}^{-1}$ & $2.98 \pm 0.13 \mathrm{a}$ & $2.63 \pm 0.10 \mathrm{~b}$ & $2.70 \pm 0.08 \mathrm{ab}$ & $2.77 \pm 0.06 \mathrm{ab}$ & $2.83 \pm 0.07 \mathrm{a}$ \\
\hline $\mathrm{Fe}$ & $\mathrm{mg} \mathrm{L}^{-1}$ & $4.86 \pm 0.57 \mathrm{a}$ & $3.53 \pm 0.63 b$ & $1.86 \pm 0.16 \mathrm{c}$ & $2.36 \pm 0.16 b c$ & $2.24 \pm 0.14 b c$ \\
\hline $\mathrm{Al}$ & $\mathrm{mg} \mathrm{L}^{-1}$ & $0.38 \pm 0.02 \mathrm{ab}$ & $0.39 \pm 0.02 \mathrm{a}$ & $0.36 \pm 0.01 \mathrm{ab}$ & $0.35 \pm 0.01 \mathrm{~b}$ & $0.34 \pm 0.01 \mathrm{~b}$ \\
\hline $\mathrm{Si}$ & $\mathrm{mg} \mathrm{L}^{-1}$ & $4.42 \pm 0.61 \mathrm{a}$ & $2.45 \pm 0.30 \mathrm{~b}$ & $1.92 \pm 0.23 \mathrm{~b}$ & $2.00 \pm 0.20 \mathrm{~b}$ & $1.84 \pm 0.24 \mathrm{~b}$ \\
\hline $\mathrm{Mn}$ & $\mathrm{mg} \mathrm{L}^{-1}$ & $0.14 \pm 0.02 \mathrm{a}$ & $0.08 \pm 0.01 \mathrm{bc}$ & $0.06 \pm 0.01 \mathrm{c}$ & $0.08 \pm 0.01 \mathrm{~b}$ & $0.08 \pm 0.01 \mathrm{~b}$ \\
\hline $\mathrm{Cl}$ & $\mathrm{mg} \mathrm{L}^{-1}$ & $4.41 \pm 0.29 \mathrm{a}$ & $3.45 \pm 0.09 \mathrm{~b}$ & $3.65 \pm 0.11 \mathrm{~b}$ & $3.66 \pm 0.08 \mathrm{~b}$ & $3.67 \pm 0.10 \mathrm{~b}$ \\
\hline $\mathrm{SO}_{4}-\mathrm{S}$ & $\mathrm{mg} \mathrm{L}^{-1}$ & $0.65 \pm 0.07 \mathrm{a}$ & $0.54 \pm 0.05 \mathrm{a}$ & $0.31 \pm 0.06 \mathrm{c}$ & $0.26 \pm 0.02 \mathrm{~b}$ & $0.22 \pm 0.02 \mathrm{bc}$ \\
\hline $\mathrm{NO}_{3}-\mathrm{N}$ & $\mathrm{mg} \mathrm{L}^{-1}$ & $0.09 \pm 0.02 \mathrm{a}$ & $0.07 \pm 0.01 \mathrm{ab}$ & $0.03 \pm 0.00 \mathrm{~b}$ & $0.06 \pm 0.01 \mathrm{ab}$ & $0.06 \pm 0.01 \mathrm{ab}$ \\
\hline $\mathrm{NH}_{4}-\mathrm{N}$ & $\mathrm{mg} \mathrm{L}^{-1}$ & $0.64 \pm 0.06 \mathrm{a}$ & $0.75 \pm 0.05 \mathrm{a}$ & $0.47 \pm 0.06 \mathrm{~b}$ & $0.30 \pm 0.03 \mathrm{~b}$ & $0.17 \pm 0.02 \mathrm{~b}$ \\
\hline $\mathrm{N}_{\text {org }}$ & $\mathrm{mg} \mathrm{L}^{-1}$ & $0.86 \pm 0.12 a b$ & $0.70 \pm 0.04 \mathrm{ab}$ & $0.88 \pm 0.06 \mathrm{ab}$ & $0.73 \pm 0.05 \mathrm{~b}$ & $0.84 \pm 0.03 \mathrm{a}$ \\
\hline $\mathrm{N}_{\text {tot }}$ & $\mathrm{mg} \mathrm{L}^{-1}$ & $1.58 \pm 0.13 \mathrm{a}$ & $1.51 \pm 0.08 \mathrm{a}$ & $1.39 \pm 0.08 \mathrm{a}$ & $1.03 \pm 0.05 \mathrm{~b}$ & $1.07 \pm 0.04 \mathrm{~b}$ \\
\hline $\mathrm{PO}_{4}-\mathrm{P}$ & $\mu \mathrm{g} \mathrm{L}^{-1}$ & $3 \pm 1 \mathrm{abc}$ & $4 \pm 0 \mathrm{c}$ & $5 \pm 0 \mathrm{a}$ & $4 \pm 0 \mathrm{ab}$ & $4 \pm 0 \mathrm{bc}$ \\
\hline $\mathrm{P}_{\text {tot }}$ & $\mu \mathrm{g} \mathrm{L}^{-1}$ & $16 \pm 1 \mathrm{a}$ & $21 \pm 2 \mathrm{a}$ & $17 \pm 2 \mathrm{a}$ & $19 \pm 1 \mathrm{a}$ & $20 \pm 1 \mathrm{a}$ \\
\hline
\end{tabular}

Mean values within rows with different letters are significantly different (ANOVA $\mathrm{p}<0.05$ ).

$N$ number of samples
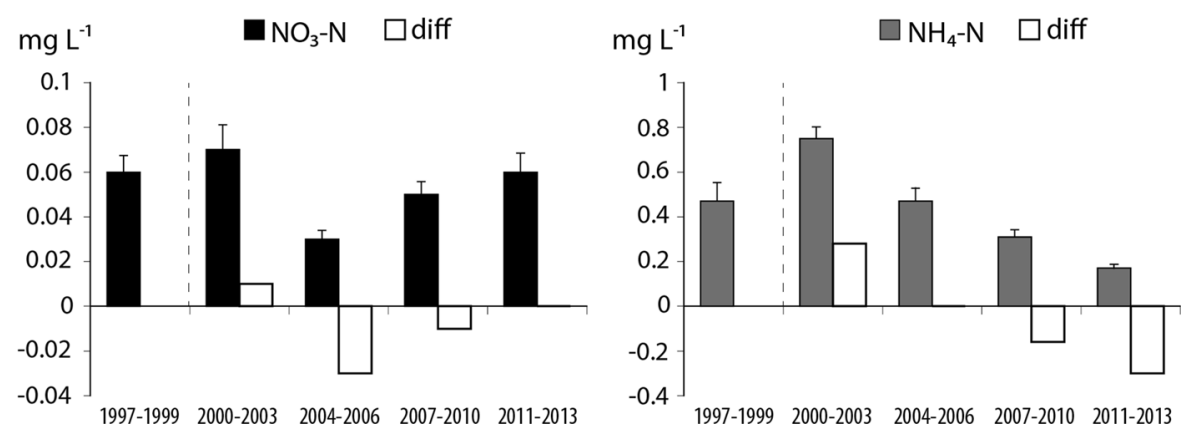

Fig. 5 Inorganic nitrogen content $\left(\mathrm{NO}_{3}-\mathrm{N}\right.$ and $\left.\mathrm{NH}_{4}-\mathrm{N}\right)$ in water of the Porla wetland before (1997-1999) and in four periods after rewetting. Black bars show measured concentrations and open bars the difference compared with before rewetting

chemical elements and compounds showed lower export after rewetting. The main exception to lower export was for $\mathrm{K}$, showing increased or unchanged export values for some periods (Table 5).

\section{Discussion}

Natural mires are totally altered after peat extraction, which turns the mire into a drained peatland (Wheeler 
Fig. 6 Phosphorus concentration $\left(\mathrm{PO}_{4}-\mathrm{P}\right.$ and $\mathrm{P}_{\text {tot }}, \mathrm{mg} \mathrm{L-1)}$ in water at the Porla wetland outlet before (1997-1999) and in four periods (1-14 years) after rewetting (black bars) and changes in Ptot (open bars) compared with calculated non-rewetted values (left). Share of $\mathrm{PO}_{4}-\mathrm{P}$ to $\mathrm{P}_{\text {tot }}$ (right)

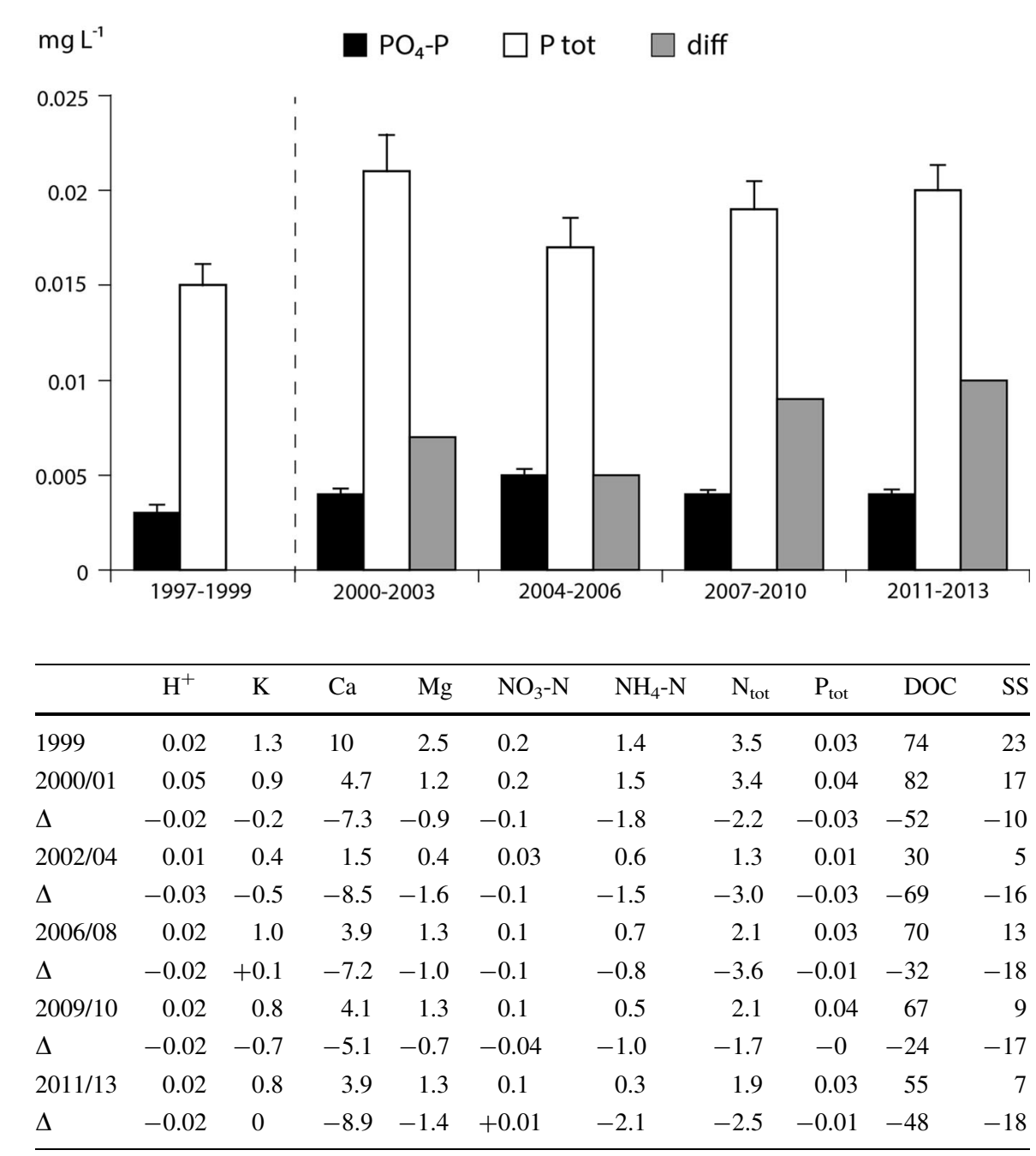

\begin{tabular}{lrrrrcrrrrr}
\hline & $\mathrm{H}^{+}$ & $\mathrm{K}$ & $\mathrm{Ca}$ & $\mathrm{Mg}$ & $\mathrm{NO}_{3}-\mathrm{N}$ & $\mathrm{NH}_{4}-\mathrm{N}$ & $\mathrm{N}_{\text {tot }}$ & $\mathrm{P}_{\text {tot }}$ & $\mathrm{DOC}$ & $\mathrm{SS}$ \\
\hline 1999 & 0.02 & 1.3 & 10 & 2.5 & 0.2 & 1.4 & 3.5 & 0.03 & 74 & 23 \\
$2000 / 01$ & 0.05 & 0.9 & 4.7 & 1.2 & 0.2 & 1.5 & 3.4 & 0.04 & 82 & 17 \\
$\Delta$ & -0.02 & -0.2 & -7.3 & -0.9 & -0.1 & -1.8 & -2.2 & -0.03 & -52 & -10 \\
$2002 / 04$ & 0.01 & 0.4 & 1.5 & 0.4 & 0.03 & 0.6 & 1.3 & 0.01 & 30 & 5 \\
$\Delta$ & -0.03 & -0.5 & -8.5 & -1.6 & -0.1 & -1.5 & -3.0 & -0.03 & -69 & -16 \\
$2006 / 08$ & 0.02 & 1.0 & 3.9 & 1.3 & 0.1 & 0.7 & 2.1 & 0.03 & 70 & 13 \\
$\Delta$ & -0.02 & +0.1 & -7.2 & -1.0 & -0.1 & -0.8 & -3.6 & -0.01 & -32 & -18 \\
$2009 / 10$ & 0.02 & 0.8 & 4.1 & 1.3 & 0.1 & 0.5 & 2.1 & 0.04 & 67 & 9 \\
$\Delta$ & -0.02 & -0.7 & -5.1 & -0.7 & -0.04 & -1.0 & -1.7 & -0 & -24 & -17 \\
$2011 / 13$ & 0.02 & 0.8 & 3.9 & 1.3 & 0.1 & 0.3 & 1.9 & 0.03 & 55 & 7 \\
$\Delta$ & -0.02 & 0 & -8.9 & -1.4 & +0.01 & -2.1 & -2.5 & -0.01 & -48 & -18 \\
\hline & & & & & & & & & &
\end{tabular}

Table 5 Annual outflow (kg ha-1 yr-1) of chemical elements from the Porla cutover site and rewetted area in periods from 1999 to 2013 , together with changes $(\Delta)$ compared with nonrewetting conditions

Mean values within rows with different letters are significantly different (ANOVA, p < 0.05) $N$ number of samples
1995). After finished industrial peat extraction, the area must be restored to an alternative use, one being new wetland. Then, the soil surface is often prepared for incoming water, drains could be closed, bunds established and other hydrotechnical installations made. Created water reservoirs change soil organic matter content, often forming anoxic bottom sediment.

Restoration after peat extraction in the Porla and Västkärr peatlands was planned within a short period of time and the commercial company involved initiated rapid restoration actions alongside ongoing peat harvesting. These conditions provided only 1-2 years for calibration measurements before rewetting. However, to our knowledge no other rewetting study has had long calibration period prior to rewetting (e.g. Tuittila et al. 1999). In the present study the necessary preparations were possible and the most difficulty was associated with hydrological determinations. The short calibration periods suffered from not having the same range of variation as the longer period after rewetting.

\section{Effects on hydrology}

Water levels in the lakes varied most in the first years of rewetting and became more stable in the longer term. The hydrological mishaps that occurred at the Porla wetland influenced discharge in two short periods, with refilling of the wetlands causing lower discharge for one period each in 2001 and 2002. In 2013 rather low runoff was measured at the Porla catchment outlet, possibly partly because of leakage at the weir for a few months. However, precipitation was low in 2013 and fairly low runoff could be expected. 
Rewetting influenced the discharge pattern, with consequences for annual, low and high discharge. Periods with low discharge, occurring often in summer periods with low precipitation, were extended after rewetting and there was an increase in number of days with no discharge, meaning cessation of stream water flow in downstream watercourses. Despite the hydrological mishaps, it could be concluded that creation of reservoirs decreased annual outlet discharge in accordance to the hypothesis, an effect also reported in other studies (Waddington et al. 2008). Rewetting by ponding water on the peat cutover area increased the frequency of days with low or no runoff from the Porla site catchment. This could be related to the increased free water surface area leading to increased evaporation. When the water level in these open water areas dropped below the outflow crest, high precipitation amounts were required to create a surplus of water for outflow discharge. Consequently, this led to a higher frequency of days with low or no runoff from the rewetting area.

Peatland drainage mainly decreases moderately high flows (Iritz et al. 1994). However, there have also been reports of increased peak flows and very high discharge peaks (Holden et al. 2006) but local conditions may modify this pattern (Shantz and Price 2006; Ballard et al. 2012). After rewetting at the Porla site, there was a decreased frequency of peak flows, especially lower peak flows. This effect was probably related to a higher lake percentage in the catchment after rewetting. Our observation that wetland restoration resulted in reduced peak flows is consistent with other studies (Wilson et al. 2010).

Grayson et al. (2010) found that increased revegetation lowered peak flows compared with bare soil. However, at Porla wetland there was no trend for lower peak flows during later years after rewetting, when vegetation cover had spread to previously bare peat areas. The variation in precipitation during the years was more important for streamflow amounts and peaks.

\section{Effects on the peat chemistry}

The concentrations of most chemical elements in the peat did not exhibit significant changes after rewetting. However, the sediment in the lakes formed due to rewetting mainly covered the superficial peat layers at the bottom of these lakes. This, together with the long- term anoxic conditions (decades) in the sediments and peat layers, probably modified some of the chemical conditions in the sediments.

The anoxic conditions in the rewetted peat at Västkärr probably also explain the drastic change in the concentration of inorganic $\mathrm{N}$ fractions. Before rewetting there was no $\mathrm{NH}_{4}-\mathrm{N}$ in the peat, only $\mathrm{NO}_{3}$ $\mathrm{N}$. Four years of rewetting raised $\mathrm{NH}_{4}-\mathrm{N}$ concentrations above $100 \mathrm{mg} \mathrm{kg}^{-1} \mathrm{dw}$, while $\mathrm{NO}_{3}-\mathrm{N}$ decreased to levels below $1 \mathrm{mg} \mathrm{kg}^{-1} \mathrm{dw}$ probably dependent on anoxic conditions. $\mathrm{NO}_{3}-\mathrm{N}$ production stops at rewetting and instead the peat organic matter starts to release ammonium (Laine et al. 2013). Pool of $\mathrm{NO}_{3}$ would partly be denitrified and also taken up by plants increasing in coverage after 5-10 years. At the nutrient-poor Porla site no such significant changes were found and instead $\mathrm{NH}_{4}-\mathrm{N}$ levels tended to decrease. $\mathrm{NO}_{3}-\mathrm{N}$ concentrations were fairly low (1-2 $\mathrm{mg} \mathrm{kg}^{-1}$ ) and decreased somewhat after rewetting. Inorganic nitrogen was instead dominated by $\mathrm{NH}_{4}-\mathrm{N} 50-200 \mathrm{mg} \mathrm{kg}^{-1}$. Probably, the fairly low $\mathrm{pH}$ and nutrient content influenced inorganic-N formation.

\section{Effects on water chemistry}

Changes in hydrology also affect water chemistry. Lakes and mires often act as retention areas, with chemical compounds stored in sediments and peat. Deviating from this is proton production in mires that increases, thereby giving comparatively lower $\mathrm{pH}$ values. The concentration of DOC may also increase, turning the water colour darker. Drainage of peatlands and wet mineral soils usually increases $\mathrm{pH}$ (Ramberg 1981) owing to organic material decomposition and leaching of mineral soil groundwater. Occasionally, short pulses of lower $\mathrm{pH}$ may occur at either very high discharges or with increasing discharge after dry periods with $\mathrm{SO}_{4}$ oxidation and $\mathrm{H}^{+}$released and washed out, (Lundin 1984). Rewetting reverses these conditions and thus in the nutrient-poor Porla site $\mathrm{pH}$ decreased. However, in the nutrient-rich Västkärr wetland the $\mathrm{pH}$ values actually increased probably because of discharging $\mathrm{CO}_{2}$-supersaturated groundwater and $\mathrm{CO}_{2}$ evasion.

Water chemistry in the Porla wetland was characterised by $\mathrm{pH}$ values commonly found in Swedish forest streams in mires ( $\mathrm{pH} \sim 5)$, putting it among the $5 \%$ of lakes with the lowest $\mathrm{pH}$ in the Swedish national 
inventory (Fölster et al. 2014). The water was dark, with a colour rating of $\sim 240 \mathrm{mg} \mathrm{Pt} \mathrm{L}{ }^{-1}$, whereas the median value for Swedish lakes is $60 \mathrm{mg} \mathrm{Pt} \mathrm{L}^{-1}$. Total organic carbon (TOC) in Porla wetland was $33 \mathrm{mg}$ $\mathrm{L}^{-1}$, compared with a median of $9 \mathrm{mg} \mathrm{L}^{-1}$ for Swedish lakes (Fölster et al. 2014). Moreover, the content of base cations was fairly high $\left(0.3 \mathrm{mEq} \mathrm{L}^{-1}\right)$ compared with the Swedish median $\left(0.2 \mathrm{mEq} \mathrm{L}^{-1}\right)$. The mean value $\mathrm{N}_{\text {tot }}$ value was $1.2 \mathrm{mg} \mathrm{L}^{-1}$ (Swedish median $0.31 \mathrm{mg} \mathrm{L}^{-1}$ ) and the mean $\mathrm{P}_{\text {tot }}$ value was $0.02 \mathrm{mg} \mathrm{L}^{-1}$ (Swedish median $0.01 \mathrm{mg} \mathrm{L}^{-1}$ ) (ibid).

Studies of peatland drainage often report lower water colour and DOC concentrations after drainage (Lundin 1988). The opposite could be expected on rewetting, but the two wetlands studied here showed mainly similar effects in drained conditions, perhaps caused by dilution of easily soluble organic matter in remaining peat by the additional water inflow. In the long run, new organic matter will be formed and this might change the water quality. The time factor is of course important. Before stable conditions are reached in the rewetted area, easily soluble substances are leached out from the superficial peat layers and sediments. Ditch blocking in blanket peatlands usually decreases DOC or water colour (Wilson et al. 2011; Armstrong et al. 2010; Strack and Zuback 2013), but some studies have found the opposite or no change (Worrall et al. 2007; Ramchunder et al. 2012). Some of the studies reporting increased levels of DOC were carried out during the first 1-3 years after restoration (Worrall et al. 2007).

The concentrations of base cations and metals often increase after peatland drainage (Sallantaus 1989) and thus rewetting could be expected to result in lower concentrations. This was in fact mainly the case in the two rewetted areas studied. The influence of the new water bodies in sedimentation storage was probably the reason.

Following peatland drainage, $\mathrm{N}$ outflows are often reported to increase, especially inorganic $\mathrm{N}$ flows, as the peat starts to decompose and oxidising conditions occur (Lundin 1988). Accordingly, rewetting lowered the $\mathrm{N}$ concentrations, but although the share of organic $\mathrm{N}$ increased, the $\mathrm{N}_{\text {tot }}$ content did not. The values were in the common range for Swedish mire and forest stream with c. $20 \%$ inorganic N (Fölster et al. 2014).

Phosphorus availability to plants is restricted in peatlands. Drainage tends to give small increases in concentration (Hooper and Morris 1982) mainly due to organic matter decomposition. However, lower phosphate concentrations after drainage of a bog have also been reported (Lundin and Bergquist 1990). Stored P in sediments can easily be released when reducing bottom conditions occurred. At the nutrient-rich Västkärr site, a significant increase in $\mathrm{P}_{\text {tot }}$ was observed after rewetting considered very high compared to Swedish lakes, while $\mathrm{PO}_{4}-\mathrm{P}$ decreased after a small initial increase in the first two years of rewetting, anyhow being on a high level (Fölster et al. 2014). The decrease was probably related to biological uptake forming organically bound $\mathrm{P}$ or $\mathrm{P}$ release from $\mathrm{Fe}$-bound $\mathrm{P}$ in the old, recalcitrant peat at the bottom of the newly established shallow lakes (Jordan et al. 2007; Zak et al. 2008). As the Västkärr area had been used for agriculture, it would be possible fertilization had been used but since about two metres of peat was removed, influence would be limited. After the initial pulse of $\mathrm{P}$ release, the $\mathrm{P}$ concentration decreased somewhat in the next 5-11 years after rewetting, but was still higher $12-15$ years after rewetting than before rewetting. However, at the nutrient-poor Porla site there were no significant effects on $\mathrm{P}_{\text {tot }}$ or $\mathrm{PO}_{4}-\mathrm{P}$ after rewetting both being on $75 \%$ percentile values compared to Swedish lakes (Fölster et al. 2014), although there was a tendency for increased $\mathrm{P}_{\text {tot }}$ values. This could be related to the vegetation development as in Västkärr site rather fast vegetation development occurred and for Porla area after about 5 years vegetation increased and with sphagnum coverage increasing after seven years (Kozlov et al. 2016).

Outflow of elements depended on discharge and the concentrations in water. In low water flow conditions, the concentrations of elements and compounds were often high, but with low water flow the contribution to fluxes was limited. In high discharge situations even low concentrations resulted in high fluxes, with consecutive consequences for annual outflows. However, the changes in leaching, with decreased flux of many elements, coincide fairly well in contrast with findings after peatland drainage, where only proton concentrations decreased (Lundin 1988). The nutrient load on downstream watercourses could be considered to decrease but $\mathrm{P}_{\text {tot }}$ outflow possibly being higher.

\section{Conclusions}

Studies at the rewetted Porla and Västkärr sites revealed storage of material, base cations and metals 
in the newly established wetlands. In particular, protons, organic nitrogen and phosphorus showed high contents in lake sediments and water. This lowered the eutrophication load, through lower flows of base cations and inorganic nitrogen being released to downstream water courses. However, in dry periods lower water runoff could have lethal consequences for surface water organisms at ceasing flow. In the long run though, as wetland vegetation develops in the area, the wetlands will revert to natural conditions, with consequences for the environment such as decreased water flow, mainly lower nutrient load but perhaps lower $\mathrm{pH}$ and higher water colour. In this study, significant effects on water chemistry appeared more clearly 8-11 years after rewetting, demonstrating the importance of monitoring for long periods after restoration to determine the full effects of rewetting.

Wetland restoration at the Porla and Västkärr sites was successful, as two functioning wetland ecosystems with stable hydrology have established after 15 years since rewetting and characteristic peatland vegetation, both fen vegetation and Sphagnum mosses have developed (Kozlov et al. 2016). This is an important prerequisite for new peat growth and a future C sink. However, the observed reduced peak flows, lower runoff and increased frequency of days with low or no runoff may have severe consequences for aquatic organisms in downstream watercourses.

The concentrations of DOC, base cations and $\mathrm{NO}_{3}-$ $\mathrm{N}, \mathrm{NH}_{4}-\mathrm{N}$ and $\mathrm{N}_{\text {tot }}$ were still lower 15 years after rewetting, but varied somewhat over time. The $\mathrm{P}_{\text {tot }}$ concentration increased, especially at the nutrient-rich Västkärr site.

While the two former cutover peatlands have reverted to natural or semi-natural lake conditions after 15 years of rewetting, there will still be changes in peat and water chemistry influencing the future wetland environment.

Acknowledgements This project was carried out at the Swedish University of Agricultural Sciences with financial support from the Swedish Energy Agency and the Swedish Peat Research Foundation. Sites were provided by Neova Company and the private landowner Per-Olof Stålhammar, who both provided valuable contributions to fieldwork. Local field observations were carried out by Sten-Ove Pettersson and Lotta Pettersson.

Funding sources Swedish Energy Agency and the Swedish Peat Research Foundation.
Open Access This article is distributed under the terms of the Creative Commons Attribution 4.0 International License (http:// creativecommons.org/licenses/by/4.0/), which permits unrestricted use, distribution, and reproduction in any medium, provided you give appropriate credit to the original author(s) and the source, provide a link to the Creative Commons license, and indicate if changes were made.

\section{References}

Armstrong A, Holden J, Kay P, Francis B, Foulger M, Gledhill S, McDonald AT, Walker A (2010) The impact of peatland drain-blocking on dissolved organic carbon loss and discolouration of water; results from a national survey. J Hydrol 381:112-120

Ballard CE, McIntyre N, Wheater HS (2012) Effects of peatland drainage management on peak flows. Hydrol Earth Syst Sci $16: 2299-2310$

Blankenburg J, Tonnis W (eds) (2004) Guidelines for wetland restoration of peat cutting areas - the BRIDGE project. EC D-RTD, EN V4-CT98-0766. Geological Survey of Lower Saxony, Bremen, p 56

Braekke FH (1970) Myrgröfting for skogsproduktion. Inflytelse på vannhusholding og flomfare. Tidskrift Skogsbruk 78:227-238 (in Norwegian)

Eggelsmann R, Heathwaite AL, Grosse-Brauckmann G, Küster E, Naucke W, Schuch M, Schweickle (1993) Physical processes and propertries of mires. In: Heathwaite AL, Görrlich Kh (eds) Mires-Process. Exploitation and Conservation, Wiley \& Sons.Chichester

Fölster J, Johnson RK, Futter MN, Wilander A (2014) The Swedish monitoring of surface waters: 50 years of adaptive monitoring. In: Lydersen, E., Löfgren, S., Fölster, J., Futter, M. and Johnson, R.K. (eds.) Fifty years of freshwater monitoring in Sweden-Special Issue of Ambio, Vol. 43. (Suplement 1); 3-18. doi 10.1007/s13280-014-0558-Z

Grayson R, Holden J, Rose R (2010) Long-term change in storm hydrographs in response to peatland vegetation change. J Hydrol 389:336-343

Grip H (1982) Water chemistry and runoff in forest streams at Kloten. UNGI Report 58. Uppsala University

Holden J, Evans MG, Burt TP, Horton MM (2006) Impact of land drainage on peatland hydrology. J Environ Qual. 35:1764-1778

Hooper FF, Morris LS (1982) Mat-water phosphorus exchange in an acid bog lake. Ecology 63:1411-1421

Iritz L, Johansson B, Lundin L (1994) Impacts of forest drainage on flodds. Hydrol Sci J 39:637-661

Schumann M, Joosten, H (2008) Global peatland restoration manual. http://www.imcg.net/media/download_gallery/ books/gprm_01.pdf. Accessed 20 April 2016

Joosten H, Clarke D (2002) Wise use of mires and peatlandsbackground and principles including a framework for decision-making. International Mire Conservation Group and International Peat Society. Saarijärvi. pp. 304 ISBN 951-97744-8-3

Jordan S, Velty S, Zeitz J (2007) The influence of degree of peat decomposition on phosphorus binding forms in fens. Mires 
and Peat 2: Art. 7. (http://www.mires-and-peat.net/pages/ volumes/map02/map0207.php). Accessed 02 Nov 2016

Jordan S, Strömgren M, Fiedler J, Lundin L, Lode E, Nilsson T (2016) Ecosystem respiration, methane and nitrous oxide emission fluxes from ecotopes in a rewetted extracted peatland in Sweden. Mires Peat 17:1-23

Kozlov SA, Lundin L, Avetov NA (2016) Revegetation dynamics after 15 years of rewetting in two extracted peatlands in Sweden. Mires Peat 18:1-17. doi:10.19189/ MaP.2015.OMB.204

Laine MPP, Strömmer R, Arvola L (2013) Nitrogen release in pristine and drained peat profiles in response to water table fluctuations: A mesocosm experiment $\mathrm{p}$ 7. Appl Environ Soil Sci. doi:10.1155/2013/694368

Lode, E (2001) Natural mire hydrology in restoration of peatland functions. Acta Universitatis Agriculturae Sueciae. Silvestria 234. PhD thesis. Swedish University of Agricultural Sciences. Uppsala. ISBN 91-576-6318-1. pp 38

Lode E, Jordan S, Lundin L, Nilsson T, Strömgren M (2012) Upscaling possibilities of environmental changes on longterm peatland management at Porla mire. Extended abstract No 228. Proceedings of the International Peat Congress, Stockholm, 2-8 June, 2012. pp 6

Lundin L (1984) Torvmarksdikning. Peatland drainage-effects on the hydrology of the mire Docksmyren. Report Series A 1984:3. Uppsala University. pp 75

Lundin L (1988) Impacts of drainage for forestry on runoff and water chemistry. In: Proc. of the int. symp. on the hydrology of wetlands in temperate and cold regions. Joensuu, Finland 6-8 June 1988. Publ. of the academy of Finland. Vol. 1. pp 197-205

Lundin L, Bergquist B (1990) Effects on water chemistry after drainage of a bog for forestry. Hydrobiologia 196:167-181

Odin H, Eriksson B, Perttu K (1983) Temperature climate maps for Swedish forestry. Reports in Forest Ecology and Forest Soils 45. pp 57 Swedish University of Agricultural Sciences, Uppsala

Raab B, Vedin, H (1995) Klimat, sjöar och vattendrag. Sveriges Nationalatlas. pp 176. Stockholm. (in Swedish)

Ramberg L (1981) Increase in stream pH after a forest drainage. Ambio Vol. X. No 1

Ramchunder SJ, Brown LE, Holden J (2012) Catchment-scale peatland restoration benefits stream ecosystem biodiversity. J Appl Ecol 49:182-191

Rochefort L, Quinty F, Campeau S, Johnson K, Malterer T (2003) North American approach to the restoration of
Sphagnum dominated peatlands. Wetlands Ecol Manage $11: 3-20$

Sallantaus T (1989) Loading of watercourses due to peat mining. Peatland ecosystem and man-an impact assessment, International Peat Society/Mires Research Group, Dundee. pp 8

Shantz MA, Price JS (2006) Characterization of surface storage and runoff patterns following peatland restoration, Quebec, Canada. Hydrol Process 20:3799-3814

SLU (2016) http://www.slu.se/institutioner/vatten-miljo/ laboratorier/vattenkemiska-laboratoriet/vattenkemiskaanalysmetoder/. Accessed 15 Nov 2016

Strack M, Zuback YCA (2013) Annual carbon balance of a peatland $10 \mathrm{yr}$ following restoration. Biogeosciences 10:2885-2896

Tuittila E-S, Komulainen V-M, Vasander H, Laine J (1999) Restored cut-away peatland as a sink for atmospheric $\mathrm{CO}_{2}$. Oecologia 120:563-574

Vasander H, Tuittila E-S, Lode E, Lundin L, Ilomets M, Sallantaus T, Heikkilä M-L, Laine J (2003) Status and restoration of peatlands in northern Europe. Wetlands Ecol Manage 11:51-63

Waddington JM, Tóth K, Bourbonniere R (2008) Dissolved organic carbon export from a cutover and restored peatland. Hydrol Process 22:2215-2224

Wheeler B, Shaw (1995) Restoration of damaged peatlands. Department of the Environment. London: HMSO. London. ISBN 0117529788

Wilson L, Wilson J, Holden J, Johnstone I, Armstrong A, Morris M (2010) Recovery of water tables in Welsh blanket bog after drain blocking: discharge rates, time scales and the influence of local conditions. J Hydrol 391:377-386

Wilson L, Wilson J, Holden J, Johnstone I, Armstrong A, Morris M (2011) Ditch blocking, water chemistry and organic carbon flux: evidence that blanket bog restoration reduces erosion and fluvial carbon loss. Sci Total Environ 409:2010-2018

Worrall F, Armstrong A, Holden J (2007) Short-term impact of peat drain-blocking on water colour, dissolved organic carbon concentration, and water table depth. J Hydrol 337:315-325

Zak D, Gelbrecht J, Wagner C, Steinberg EW (2008) Evaluation of phosphorus mobilization potential in rewetted fens by an improved sequential chemical extraction procedure. Eur J Soil Sci 59:1191-1201. doi:10.1111/j.1365-2389.2008. 01081.x 